\title{
SPONTANEOUS SUBCAPSULAR RENAL HEMATOMA AS A COMPLICATION OF ACUTE PYELONEPHRITIS: A CASE REPORT
}

Ivan Jankovic $^{1}$, Tomislav Nikolic ${ }^{2,5}$, Slobodanka Mitrovic ${ }^{3,5}$, Radisa Vojinovic ${ }^{4,5}$

${ }^{1}$ Department of Radiology, General hospital Uzice, Health center Uzice

${ }^{2}$ Center for Nephrology and Dialysis, Clinical center „Kragujevac"

${ }^{3}$ Department of Pathological Anatomy, Clinical center "Kragujevac"

${ }^{4}$ Department of Radiology, Clinical center "Kragujevac"

${ }^{5}$ Faculty of Medical Sciences, University of Kragujevac

\author{
SPONTANI SUBKAPSULARNI HEMATOM BUBREGA IKAO \\ KOMPLIKACIJA AKUTNOG PIJELONEFRITISA: PRIKAZ SLUČAJA \\ Ivan Janković1, Tomislav Nikolić ${ }^{2,5}$, Slobodanka Mitrović ${ }^{3,5}$, Radiša Vojinović ${ }^{4,5}$ \\ Služba za radiološku dijagnostiku, Opšta bolnica Užice, Zdravstveni centar Užice \\ ${ }^{2}$ Centar za nefrologiju i dijalizu, Klinički centar "Kragujevac" \\ ${ }^{3}$ Služba za patologiju, Klinički centar "Kragujevac" \\ ${ }^{4}$ Služba za radiološku dijagnostiku, Klinički centar "Kragujevac" \\ Fakultet medicinskih nauka, Univerzitet u Kragujevcu
}

Received / Primljen: 07.05.2016.

Accepted / Prihvaćen: 04.11.2016.

\begin{abstract}
Spontaneous subcapsular renal hematoma (SSRH) emerged as a complication of acute pyelonephritis (APN) is an extremely rare condition. We showed a patient aged 63 years hospitalized due to languor, febrility, abdominal pain accompanied by nausea and vomiting. Ultrasound (US) examination of the abdomen and multidetector computed tomography (MDCT) showed the presence of subcapsular hematoma of the left kidney with calculus in the initial part of the left ureter. Laboratory tests registered a positive inflammation syndrome, anemia and an increase in nitrogen compounds. Based on laboratory results, clinical presentation and imaging techniques it has been found that it is APN with spontaneous subcapsular hematoma. After application of non-surgical treatment which included antibiotic therapy with percutaneous drainage of hematoma, a good clinical response with regression of subjective symptoms and hematoma was obtained. On repeated US and MDCT after 18 months no pathological changes in the kidneys were registered. Spontaneous subcapsular hematoma extremely rare occurs as a result of APN associated with calculosis. The use of non-surgical treatment, which includes appropriate antibiotic therapy with percutaneous drainage of hematoma would represent a method of first choice.
\end{abstract}

\section{SAŽETAK}

Spontani subkapsularni hematom bubrega (SSHB) nastao kao komplikacija akutnog pijelonefritisa (APN) je izuzetno retko stanje. Prikazali smo pacijentkinju starosti 63 godine hospitalizovanu zbog malaksalosti, febrilnosti, bola u trbuhu praćenim mučninom $i$ povraćanjem. Ultrazvukom (UZ) i multidetektorskom kompjuterizovanom tomografijom (MDCT) abdomena dokazano je prisustvo subkapsularnog hematoma levog bubrega sa kalkulusom u početnom delu levog uretera. Laboratorijskim pretragama registrovani su pozitivan zapaljenjski sindrom, anemija kao i porast azotnih materija. Na osnovu pomenutih laboratorijskih nalaza, kliničke slike kao i vizualizacionih tehnika utvrdeno je da se radi o APN sa spontanim subkapsularnim hematomom. Nakon primene nehirurškog tretmana koji je podrazumevao antibiotsku terapiju sa perkutanom drenažom hematoma dobijen je dobar klinički odgovor sa regresijom subjektivnih tegoba kao i hematoma. Na ponovljenom UZ i MDCT pregledu nakon 18 meseci nisu registrovane patološke promene na bubrezima. Spontani subkapsularni hematom izuzetno retko nastaje kao posledica APN udruženog sa kalkulozom. Primena nehirurškog tretmana koji podrazumeva odgovarajuću antibiotsku terapiju sa perkutanom drenažom hematoma bi predstavljala metodu prvog izbora.

Ključne reči: spontani subkapsularni hematom bubrega, pijelonefritis, perkutana drenaža

Keywords: spontaneous subcapsular renal hematoma, pyelonephritis, percutaneous drainage

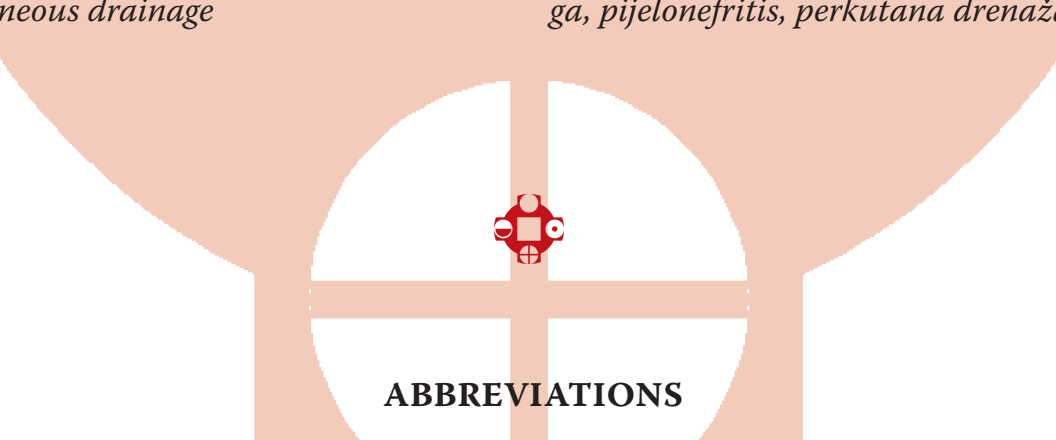

SSRH- Spontaneous subcapsular renal hematoma APN - Acute pyelonephritis MDCT - Multidetector computed tomography US - Ultrasound 


\section{INTRODUCTION}

Spontaneous subcapsular renal hematoma (SSRH) emerged as a complication of acute pyelonephritis (APN) is an extremely rare condition. In recent years, thanks to advances in imaging procedures like US and MDCT, diagnosis of disease was significantly facilitated. A decision about the treatment of disease represents a dilemma, in the sense that the surgical treatment that involves radical nephrectomy should be implemented or apply another approach to treatment. Previously it was considered that the most common cause of SSRH was a kidney tumor with no obvious etiology, therefore a radical nehrectomy was always advised.

We have presented a case of a woman with APN and ureteral calculosis with the creation of a SSRH as a complication. By applying non-surgical treatment, which includes antibiotic therapy with percutaneous drainage of hematoma (intervention radiological procedure), optimal therapeutic response and complete regression of hematoma and clinical symptoms were obtained.

\section{CASE REPORT}

A woman aged 63 years was admitted to the Center for Emergency Medicine with the complaints in the form of fatigue, fever, vomiting and abdominal pain, predominantly in the left lumbar flunk. These symptoms last for two days backward. On admission she denied the existence of any injury. She did not give information about the existence of other diseases, nor was treated. Laboratory analyzes indicated the positive inflammatory syndrome: Sed Rate $86 \mathrm{~mm} / \mathrm{h}$, CRP $186 \mathrm{mg} / \mathrm{L}$, Le $12.1 \times 10^{9}$. Other laboratory analysis indicated the presence of anemia Er $2.81 \times 10^{12}$, $\mathrm{Hgb} 68 \mathrm{~g} / \mathrm{L}, \mathrm{HCT} 0.213$ and also the presence of asothaemia (urea $24.8 \mathrm{mmol} / \mathrm{L}$, creatinine $375 \mu / \mathrm{L}$ ) ionogram and hepatogram were within the normal range. The finding in the urine is indicated for bacteriuria with piuria.

By US examination of the abdomen, it can be seen, together with the lateral contour of the left kidney, hypoechogenic, ovoid area, diameter $155 \times 47 \mathrm{~mm}$, which surrounds the kidney (figure 1). Doppler examination did not show any arteriovenous fistula as a cause of the collection. MDCT confirms the existence of SSRH, with the inclusions of gas (figure 2). Compression of parenchyma and collecting system of the kidney is noticeable, with no signs of intrarenal hematoma, and also at the beginning of the left uretere there is a calculus $20 \times 13 \mathrm{~mm}$ in size, with minimal urinary retention.

Based on the findings of MDCT a decision was taken on further non-surgical treatment of SSRH. With the empirical use of antibiotics a percutaneous drainage of collection by "pigtail" 9F catheter was performed. About $200 \mathrm{ml}$ of non-homogeneous, hemorrhagic content was drained from whom the bacterium Escherichia coli was isolated and also confirmed in the urine culture.

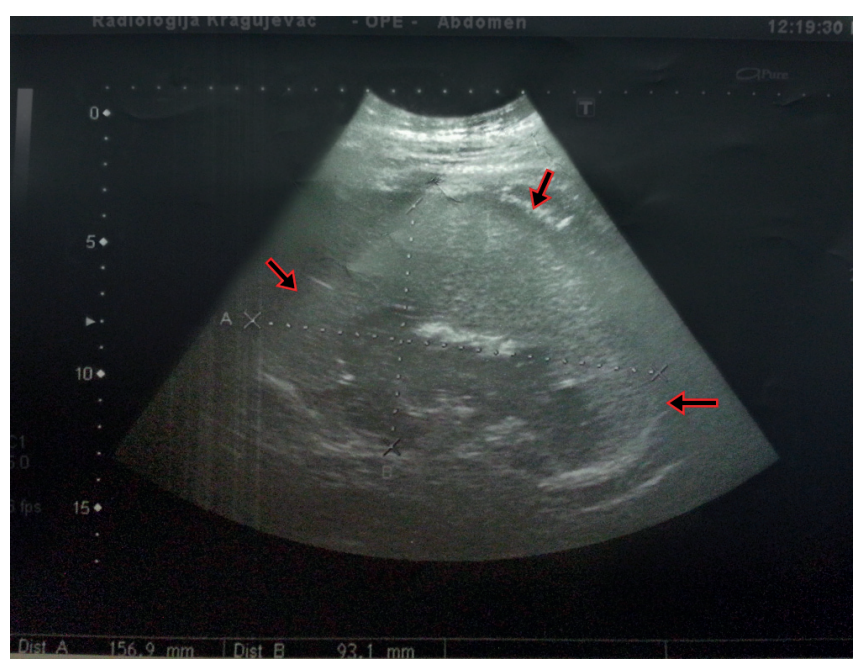

Figure 1. US of left kidney shows hypoechogenic, ovoid area which surrounds the kidney

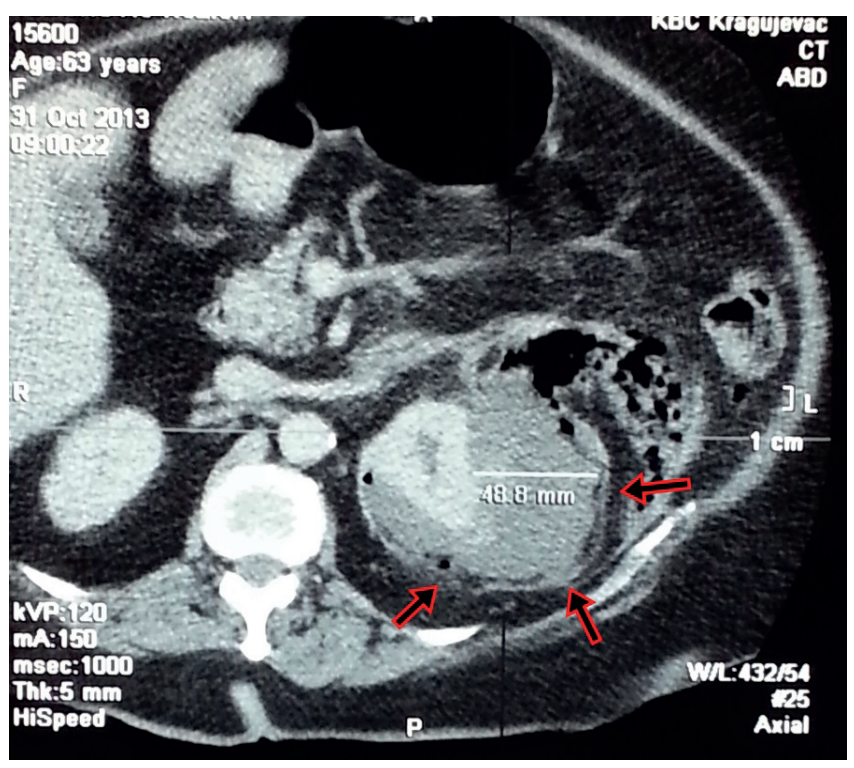

Figure 2. MDCT confirms the existence of subcapsular haemathoma, with the inclusions of gas. Arrows show the presents of hematoma.

After drainage and antibiotic therapy acording to the antibiogram the patient feels better, laboratory analyses show regression of inflammatory syndrome. Control US and MDCT confirms the regression of changes (figure 3). After 12 days, the patient was discharged from hospital. By subsequent MDCT control after 18 months there were no new renal changes registered (figure 4).

\section{DISCUSSION}

Spontaneous subcapsular hematoma of the kidney can be divided into three types: intrarenal, perirenal and subcapsular hematoma. It generally occurs as a result of other pathological conditions, like tumors, vascular diseases, extremely rare as a result of infection, or other 
causes, including the state of an unknown etiology $(1,2)$. Very rarely SSRH may occur as a complication of APN, and in the available literature, we found only three such cases (3-5). In the clinical picture dominates general symptomatology (fatigue, pain, fever), and a decrease in hemoglobin (6). Meta analysis shows that the most common causes of SSRH are tumors - 61.5\%. Malignant tumors (most commonly renal cell carcinoma) are responsible for $31.5 \%$ and benign (most angiomyolipoma) to $29.7 \%$. Vascular disease causes SSRH to $17 \%$, infection in $2.4 \%$ and $6.7 \%$ of cases of idiopathic etiology (1). In the literature as a rare cause of SSRH are mentioned hypertension, anticoagulation, nimesulide, percutaneous angiography (6-9). US is useful for rapid identification of findings, but the diagnosis must be confirmed by MDCT examination, which is the method of choice. MDCT has a high sensitivity and specificity to confirm the existence of hematoma, as well as the cause of its occurrence $(1,9)$. Regarding the therapeutic approach, a number of authors in their work suggest that the best solution is non-surgical treatment, which involves percutaneous drainage of the hematoma (as a intervention radiological procedure), with the elimination of the basic causes of this disease (6-8).

This attitude is confirmed by the authors, which refer APN as a cause of SSRH (3-5). In the presented case we highlight the importance of timely and adequate diagnostic approach (US, MDCT), and then, in accordance with the diagnosis of the underlying cause, the implementation of appropriate antibiotic therapy (according to the antibiogram), as well as percutaneous drainage of SSRH. APN potentiated by the presence of kidney stone in the proximal part of the ipsilateral ureter, we claim, can give SSRH as a complication. Non-surgical treatment provides an adequate solution, not only because of the drainage of the hematoma, but also for the confirmation of bacterial pathogens, and therefore application of effective antibiotics.

In conclusion, an extremely rare SSRH occurs as a result of an APN associated with calculosis and the use of non-surgical treatment (antibiotics with percutaneous drainage) is the first line of choice.

\section{REFERENCES}

1. Zhang JQ, Fielding JR, Zou KH. Etiology of spontaneous perirenal hemorrhage: a meta-analysis. J Urol 2002; 167(4): 1593-6.

2. $\mathrm{Mu} \mathrm{Q}$, Xiao S, Wan Y. Spontaneous renal hemorrhage caused by invasive mole: a case report. J South Med Univ 2015; 35(2): 309-11.

3. You CF, Chong CF, Wang TL, Chen CC. Subcapsular renal hematoma complicating acute pyelonephritis. J Emerg Med 2010; 39(4): 440-2.

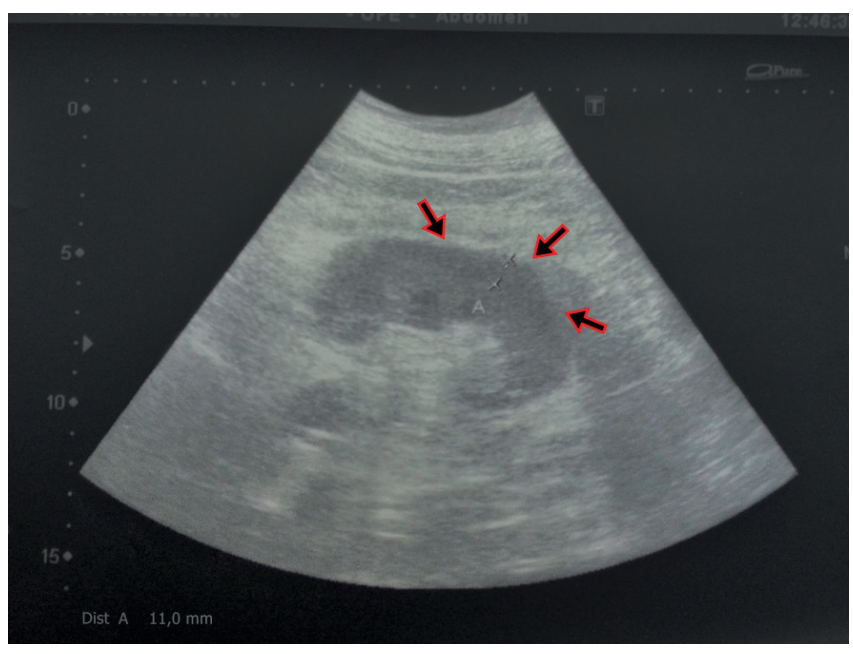

Figure 3. US shows the regresion of hematoma.

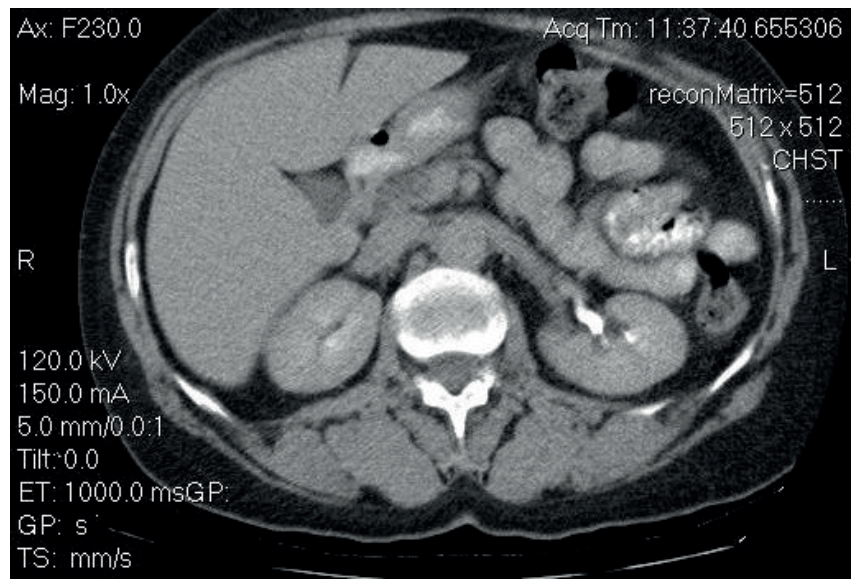

Figure 4. By subsequent MDCT control after 18 months there were no new renal changes registered.

4. Kim HJ, Kim SW, Jang WY, Kim YS, Park CK. Subcapsular hematoma as a complication of acute pyelonephritis: a case report. J Korean Med Sci 1998; 13: 551-3.

5. Jemni H, Tlili K, Saad J, Bakir D, Belguith M, Bouchoucha S, Kraiem C. Subcapsular hematoma complicating acute pyelonephritis. J Radiol 1996; 77(8): 575-8.

6. Baishya RK, Dhawan DR, Sabnis RB, Desai MR. Spontaneous subcapsular renal hematoma: a case report and review of literature. Urol Ann 2011;3(1):44-6.

7. Ferrando F, Budia A, Mira Y, Vaya A, Aznar J. Spontaneous renal subcapsular hematoma in an anticoagulated patient. Clin Appl Thromb Hemost 2006; 12(1): 89-92.

8. Mitsogiannis IC, Chatzidarellis E, Skolarikos A, Papatsoris A, Anagnostopoulou G, Karagiotis E. Bilateral spontaneous retroperitoneal bleeding in a patient on nimesulide: a case report. J Med Case Rep 2011; 5(1): 568.

9. JS Yi, HJ Lee, HJ Lee, JH Yang. Renal subcapsular hematoma after percutaneous transfemoral angiography. J Korean Neurosurg Soc 2014; 55(2): 96-8. 